\title{
The effect of changes of dietary calcium concentration on calcium metabolism in sheep
}

\author{
BY G. D. BRAITHWAITE \\ National Institute for Research in Dairying, Shinfield, Reading RG2 9AT
}

$$
\text { (Received I7 May 1973-Accepted } 5 \text { October 1973) }
$$

\footnotetext{
I. The effect of changes of dietary calcium concentration on Ca metabolism in eight adult wethers has been studied by the use of balance and radioactive techniques.

2. Animals receiving an adequate $\mathrm{Ca}$ intake absorbed sufficient $\mathrm{Ca}$ to supply their maintenance requirements only; a change in intake resulted in a corresponding change in the rate of absorption and disturbed this Ca balance. The new rate of absorption appeared to be determinded by the Ca concentration of the new diet and the efficiency of absorption of Ca from the previous diet.

3. Provided the new diet contained sufficient available $\mathrm{Ca}$, animals quickly altered their efficiency of absorption of $\mathrm{Ca}$ until they were again absorbing enough for maintenance only.

4. When a lack of available $\mathrm{Ca}$ in the diet made it impossible for them to meet their maintenance requirements, they slowly reduced faecal endogenous excretion of $\mathrm{Ca}$.

5. Ca-deficient animals absorbed $\mathrm{Ca}$ at a very high rate when given a diet plentiful in $\mathrm{Ca}$, and absorption decreased only when all the previous losses had been restored.

6. Ca-deficient animals also mobilized $\mathrm{Ca}$ reserves more readily in response to a severe loss of blood Ca than did animals which were not deficient.

7. Retention of $\mathrm{Ca}$ was directly related to the rate of absorption of $\mathrm{Ca}$ and inversely related to the rate of resorption of $\mathrm{Ca}$ from bone.

8. The results indicate that resorption of $\mathrm{Ca}$ from bone is the major process involved in $\mathrm{Ca}$ homoeostasis and that $\mathrm{Ca}$ absorption is responsible for the long-term control of Ca metabolism and in particular for maintaining body $\mathrm{Ca}$ reserves.
}

The effects of changes of dietary calcium concentration on Ca metabolism in the ruminant have not been studied in detail and the few reports on this subject are conflicting. Braithwaite \& Riazuddin (1971) found that adult sheep, irrespective of their dietary $\mathrm{Ca}$ concentration, absorbed sufficient $\mathrm{Ca}$ to supply their maintenance requirements only. Scott (1965), however, reported that they absorbed $\mathrm{Ca}$ in direct relation to their intestinal $\mathrm{Ca}$ concentration, and Braithwaite \& Riazuddin (I97r) found that young growing sheep did likewise. Visek, Monroe, Swanson \& Comar (1953) found that, although some cows absorbed more Ca when the intake was increased, others did not and Manston (1967) found that this increase in absorption lasted for only a few days.

It is well known that man and rat adapt to changes in the Ca concentration of the diet by altering the efficiency of absorption of $\mathrm{Ca}$ from the intestine (Malm, 1963 ; Zornitzer \& Bronner, I97I) and it seems possible that similar adaptations occur in the ruminant.

The purpose of the present work was to investigate in detail the effects of changes in $\mathrm{Ca}$ intake on the various processes of $\mathrm{Ca}$ metabolism in the adult sheep and to obtain information on the possible mechanisms involved in the control of $\mathrm{Ca}$ absorption. 


\section{EXPERIMENTAL}

Animals, housing and diet. Eight 2-year-old Dorset-Horn wethers weighing 50-60 $\mathrm{kg}$ were used for these investigations. They were housed in metabolism cages designed for the separate collection of urine and faeces and had free access to distilled-water.

It was calculated from results of Braithwaite \& Riazuddin (1971) that sheep required $55 \mathrm{mg} \mathrm{Ca} / \mathrm{d}$ per kg body-weight in the diet to supply their maintenance requirements. In the present experiments, sheep were given low-, normal- or highCa diets of such a composition (see Table I) that the low one supplied less than this amount of $\mathrm{Ca}(27.4 \mathrm{mg} / \mathrm{kg}$ body-weight), the normal one approximately twice this amount of $\mathrm{Ca}(115.2 \mathrm{mg} / \mathrm{kg}$ body-weight) and the high one three-to-four times this estimated requirement $(180.4 \mathrm{mg} / \mathrm{kg}$ body-weight). The ratio Ca:phosphorus in the three diets differed considerably. Ruminants, however, have been shown to tolerate considerable variations in this ratio without any interference in utilization of either the $\mathrm{Ca}$ or $\mathrm{P}$ (Lueker \& Lofgreen, I96r; Young, Richards, Lofgreen \& Luick, rg66).

Experimental design. All eight animals received the normal- $\mathrm{Ca}$ diet of hay and concentrates for the first $\mathrm{x} 2$ weeks of the experiment. Four, chosen at random, were then given the high-Ca diet for 12 weeks and then the normal diet again. The other four were maintained on the low-Ca diet for $3^{8}$ weeks, after which they were given the high-Ca diet for a further 18 weeks.

Weekly $\mathrm{Ca}$ balances were measured for each animal throughout the whole of the experimental period and, in addition, kinetic studies were made at various times on the different diets. Faeces collected the day after a change of diet were discarded because it has been found that there is an $\mathrm{I} 8 \mathrm{~h}$ time lag for passage of food through the gastrointestinal tract (unpublished observations).

Infusion of ethylenediaminetetraacetic acid (EDTA). The response to a severe loss of blood $\mathrm{Ca}$ caused by the intravenous infusion of EDTA was measured in the first four sheep 12 weeks after they had returned to the normal-Ca diet and in the other four sheep after 20 weeks on the low-Ca diet. An aqueous solution of EDTA ( $100 \mathrm{~g} / \mathrm{l}$ ) was infused for $4 \mathrm{~h}$ at a rate of $20 \mathrm{ml} / \mathrm{h}$ through a cannula inserted into one jugular vein, and blood samples were withdrawn from the other jugular vein 0 , $0.25,0.5, \mathrm{I}, 2,3,4,5,6,9, \mathrm{I} 2$ and $24 \mathrm{~h}$ after the beginning of the infusion.

Methods. The methods used for the determination of $\mathrm{Ca}$ and the measurement of radioactivity in samples of blood, faeces and urine have been described previously (Braithwaite, Glascock \& Riazuddin, 1969). Uncomplexed serum Ca in the EDTA infusion experiments was measured by EDTA titration with murexide as indicator. Total $\mathrm{P}$ was determined in ashed samples of food by the method of Goldenberg \& Fernandez (1966). Kinetic studies were performed by the method of Aubert \& Milhaud ( 1960 ) modified for use with sheep (Braithwaite et al. 1969; Braithwaite \& Riazuddin, x971). 
Vol. 31

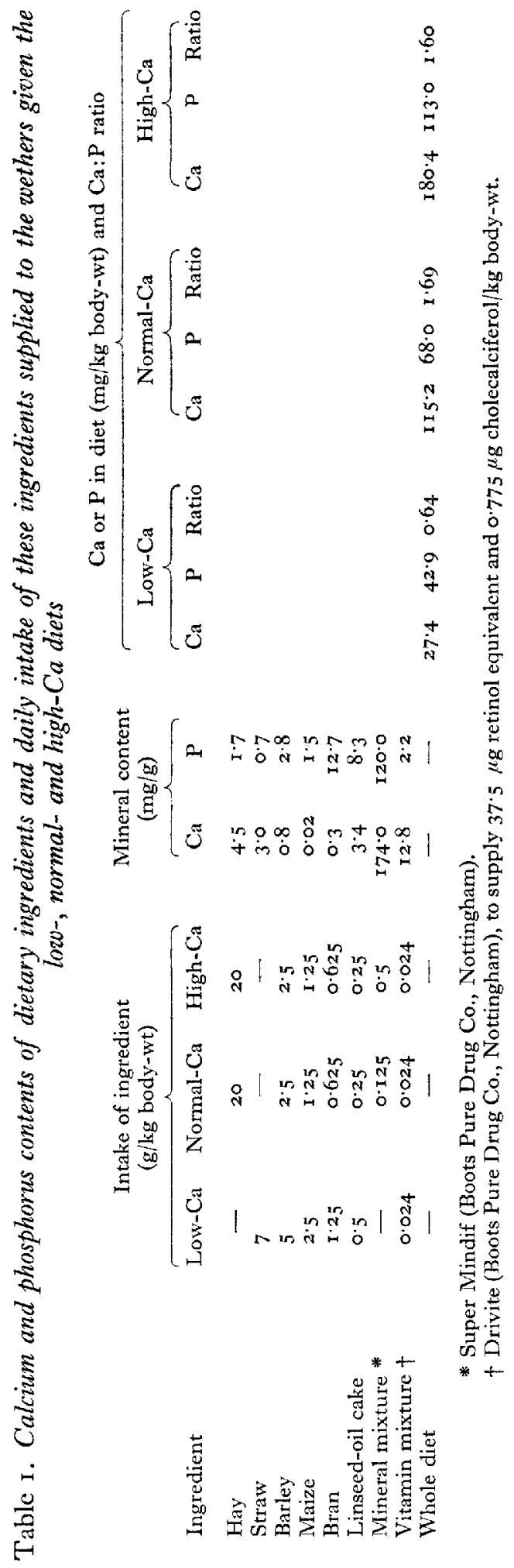




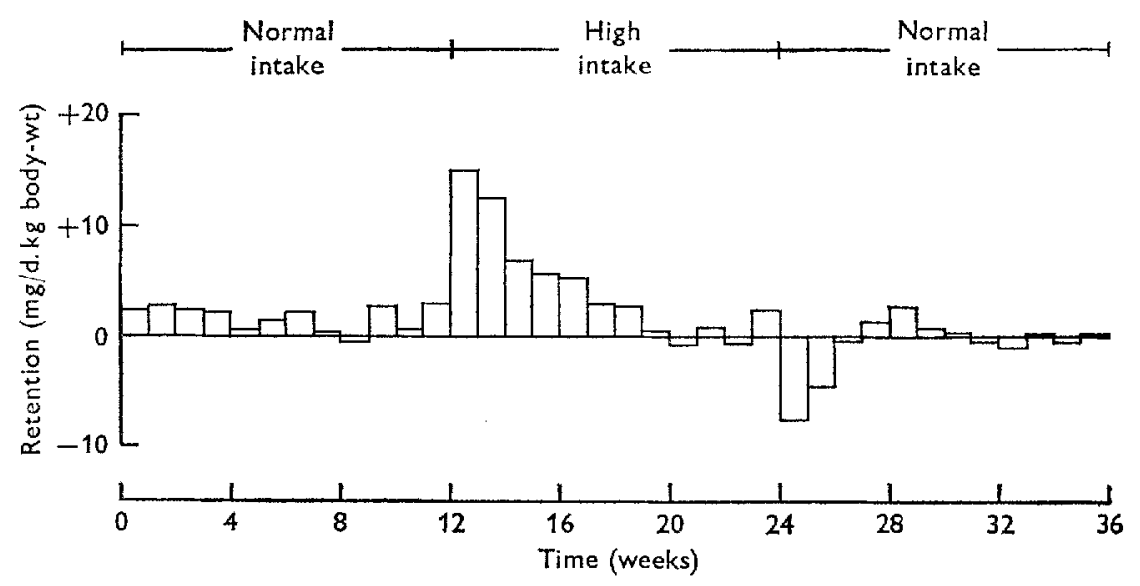

Fig. I. Effect of changes of calcium intake on Ca retention by wethers (mean values for four animals).

\section{RESULTS}

Fig. I shows the results of $\mathrm{Ca}$ balance measurements on sheep transferred from the normal- $\mathrm{Ca}$ to the high-Ca and back to the normal-Ca diet, and Table 2 the results of kinetic studies made on these animals.

On transfer to the high-Ca diet, $\mathrm{Ca}$ excretion, which was approximately equal to intake in animals given the normal-Ca diet, increased less than did intake. This resulted in a marked increase in $\mathrm{Ca}$ retention. Retention then quickly decreased as excretion increased and the equilibrium between excretion and intake was re-established.

The kinetic studies (Table 2) show that the temporary increase in retention was due entirely to an increased rate of $\mathrm{Ca}$ absorption and that adaptation to the high-Ca dict was achieved by a decrease in the efficiency of absorption of Ca. More Ca was excreted than was present in the diet immediately after animals were transferred back to the normal-Ca diet and this resulted in a marked loss of body $\mathrm{Ca}$. Kinetic studics (Table 2) show that this loss was due to a decrease in the rate of Ca absorption and that adaptation to the normal-Ca diet that took place in the following weeks was again achieved by an alteration in the efficiency of absorption.

Since faecal endogenous excretion of $\mathrm{Ca}$ was unaltcred by changes in $\mathrm{Ca}$ intake (Table 2), its mean value ( $17.7 \mathrm{mg} / \mathrm{d}$ per $\mathrm{kg}$ body-weight), determined in the kinetic studies, can be used in the following equation to calculate $\mathrm{Ca}$ absorption tates in the weeks immediately before and after the changes in dietary $\mathrm{Ca}$ intake:

$$
V_{a}=V_{i}+V_{f}-F,
$$

where $V_{a}$ is the rate of absorption of $\mathrm{Ca}$ from the intestine, $V_{i}$ the rate of ingestion of $\mathrm{Ca}, V_{f}$ the rate of excretion of $\mathrm{Ca}$ into the intestine (faecal endogenous $\mathrm{Ca}$ ) and $F$ the rate of loss of $\mathrm{Ca}$ in the faeces.

Fig. 2 summarizes the effects of these changes of intake on $\mathrm{Ca}$ absorption. Transfer of the animals from the normal- $\mathrm{Ca}$ ( $106 \mathrm{mg} / \mathrm{d}$ per $\mathrm{kg}$ body-weight) to the high-Ca 


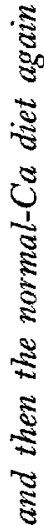

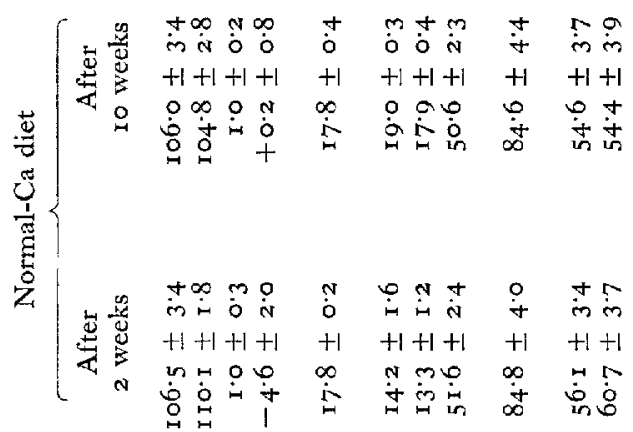

s.

羡

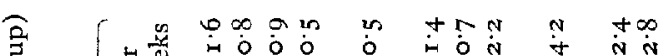
$\approx$ 至

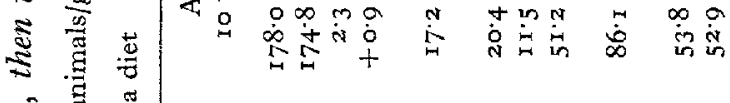

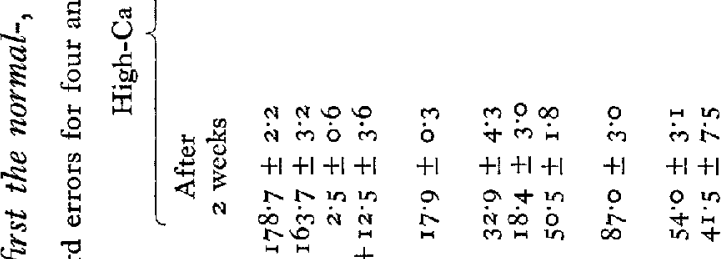

苞

3 至

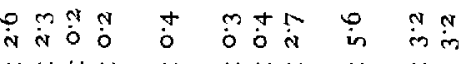
$+1+1+1+1 \quad+1+1+1+1 \quad+1+1+1$

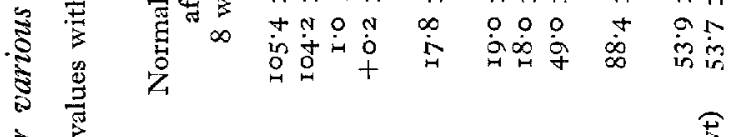




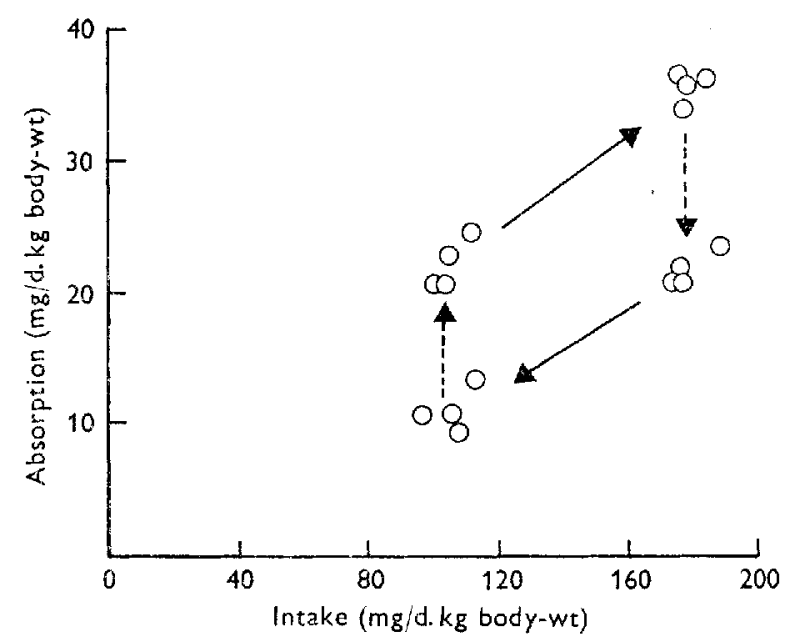

Fig. 2. Variation in the rate of calcium absorption by wethers with changes in $\mathrm{Ca}$ intake. , rapid change in absorption following the change in intake; - change in absorption as animals adapted to the new intake.

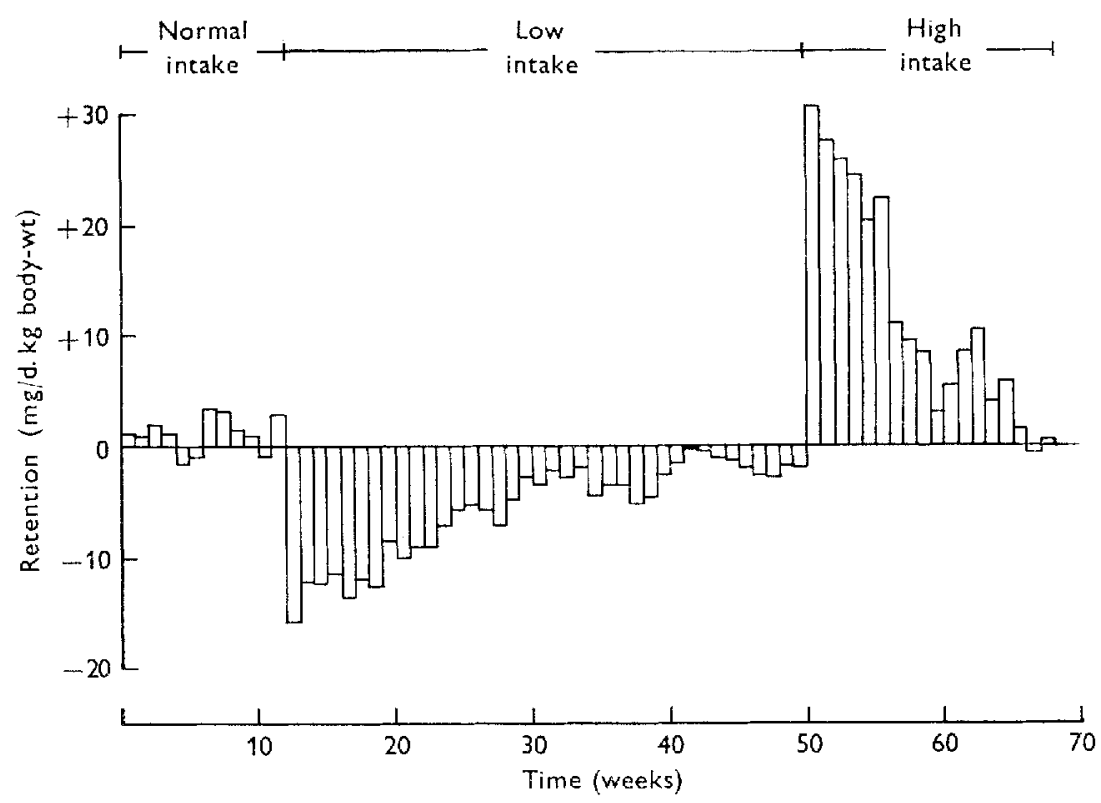

Fig. 3. Effect of changes of calcium intake on $\mathrm{Ca}$ retention by wethers (mean values for four animals).

$(178 \mathrm{mg} / \mathrm{d}$ per $\mathrm{kg}$ ) diet resulted in an immediate increase in Ca absorption from approximately $22 \mathrm{mg} / \mathrm{d}$ per $\mathrm{kg}$ to $35 \mathrm{mg} / \mathrm{d}$ per $\mathrm{kg}$. The efficiency of absorption, however, was unchanged $(20.7$ and $19.7 \%$ respectively). During the following weeks, absorption gradually decreased back to $22 \mathrm{mg} / \mathrm{d}$ per $\mathrm{kg}$ as adaptation to the high intake took place. When animals were transferred back to the normal-Ca diet, 


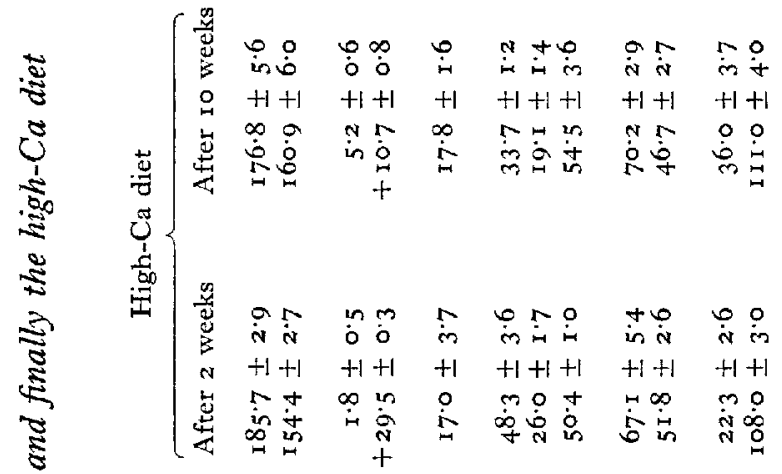

帘

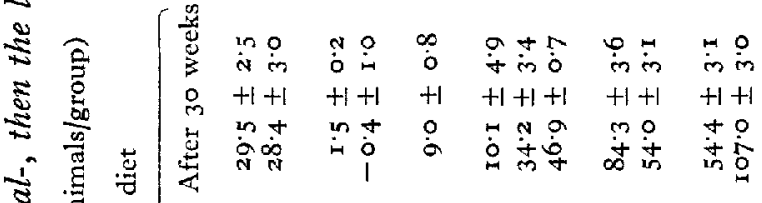

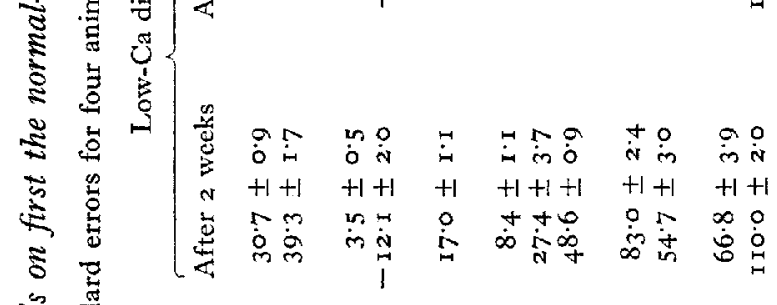

造

矛

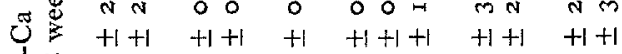

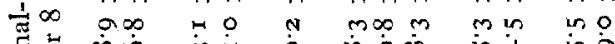

i

$\stackrel{s}{\stackrel{5}{8}}$

\&

5

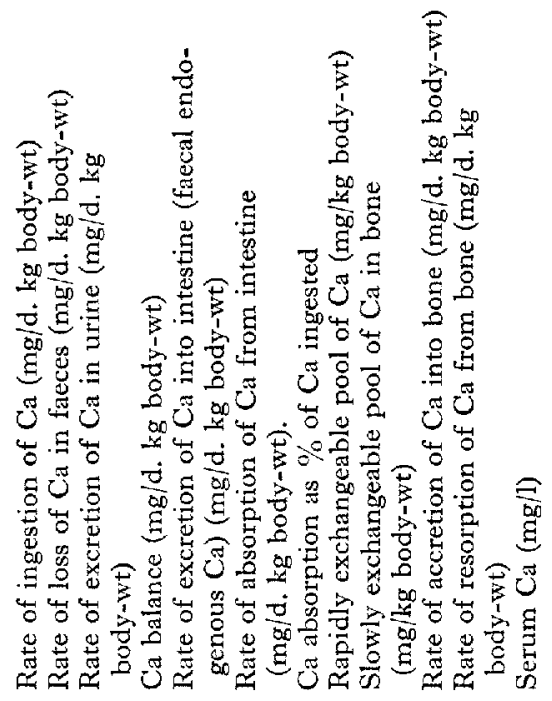




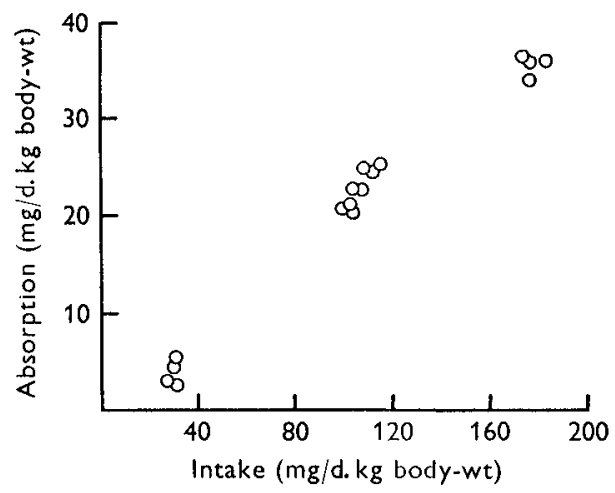

Fig. 4. Relationship between calcium intake and the rate of $\mathrm{Ca}$ absorption by wethers.

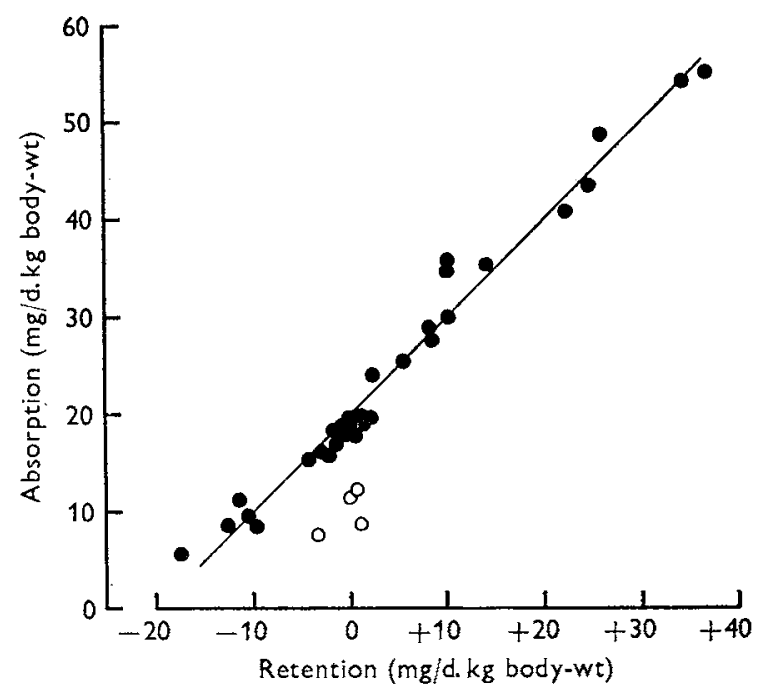

Fig. 5. Relationship between calcium retention $(\Delta)$ and the rate of absorption of $\mathrm{Ca}\left(\mathrm{V}_{a}\right)$ by wethers. $\mathrm{V}_{a}=19 \cdot 7+\mathrm{I} \cdot \mathrm{Or} \Delta$. Wethers after various periods on the normal- and high-Ca diets and before adaptation to the low-Ca diet; $O$, wethers after adaptation to the low-Ca diet.

absorption immediately decreased to a very low level (i I $\mathrm{mg} / \mathrm{d}$ per $\mathrm{kg}$ ) but again the efficiency of absorption remained fairly constant (12.3 and $10.4 \%$ ). The rate of absorption then gradually returned to its original value $(22 \mathrm{mg} / \mathrm{d}$ per $\mathrm{kg}$ ) as adaptation to the normal-Ca diet occurred.

These results show that the amount of $\mathrm{Ca}$ absorbed from a given diet varied as animals became adapted to the diet. Before adaptation (i.e. immediately after a change in intake) the rate of absorption appeared to be determined by the efficiency of absorption of $\mathrm{Ca}$ from the previous diet and the relative concentrations of $\mathrm{Ca}$ in the present and previous diets, whereas after adaptation had taken place it appeared to be related only to $\mathrm{Ca}$ requirements.

Fig. 3 shows the results of Ca-balance measurements on animals transferred from 
Vol. $3^{1}$

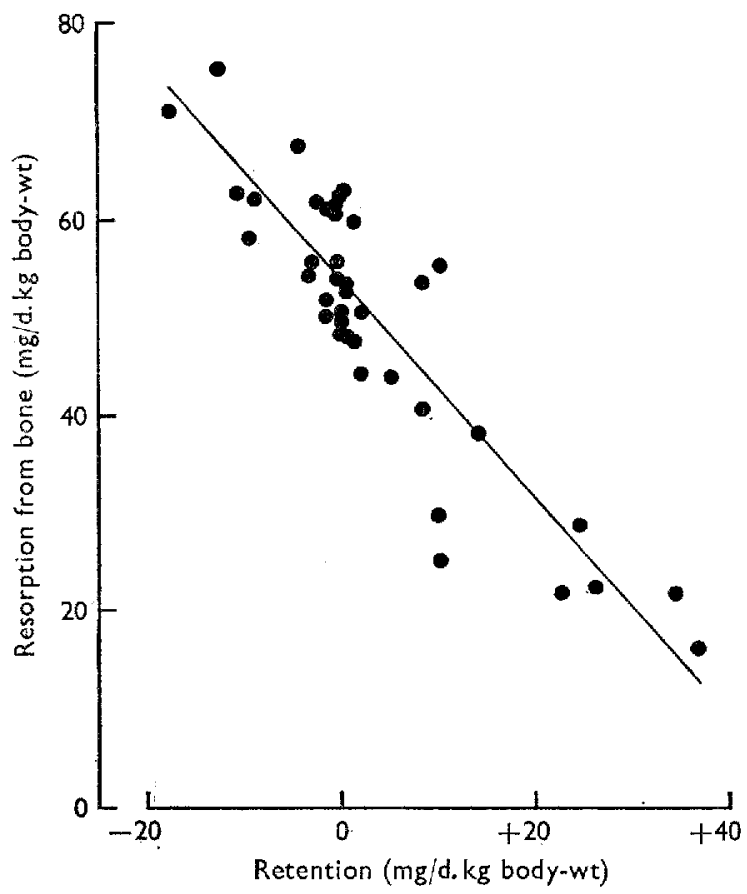

Fig. 6. Relationship, in wethers, between calcium retention $(\Delta)$ and the rate of resorption of Ca from bone $\left(\mathrm{V}_{0}-\right)$. $\mathrm{V}_{0}-=53 \cdot 8-\mathrm{I} \cdot \mathrm{I} \Delta$.

the normal to the low and finally to the high $\mathrm{Ca}$ intake and Table 3 the results of kinetic studies performed on these animals.

Animals that on the normal-Ca diet were in Ca balance showed a marked net loss of $\mathrm{Ca}$ when transferred to the $\mathrm{Ca}$-deficient diet. This loss gradually decreased in the following $16-20$ weeks, but remained fairly steady at approximately $2 \mathrm{mg} / \mathrm{d}$ per $\mathrm{kg}$ body-weight for the remainder of the period on the diet. Kinetic studies (Table 3) show that the large initial net loss of $\mathrm{Ca}$ resulted from a decreased rate of $\mathrm{Ca}$ absorption and that adaptation to the Ca-deficient diet was due mainly to a decrease in the rate of faecal cndogenous excretion of $\mathrm{Ca}$; alterations in the efficiency of absorption played only a minor part, its mean value increasing from $27.4 \%$ after 2 weeks on the diet to only $34.4 \%$ after 30 weeks.

Animals lost approximately $\mathrm{I} \cdot 5 \mathrm{~g} \mathrm{Ca} / \mathrm{kg}$ body-weight during the 38 weeks on the $\mathrm{Ca}$-deficient diet which, if it is assumed that the mcan $\mathrm{Ca}$ content of sheep is 8.9 $\mathrm{g} / \mathrm{kg}$ body-weight (Agricultural Research Council, 1965 ), is equivalent to $17 \%$ of total body $\mathrm{Ca}$.

Retention of $\mathrm{Ca}$ increased to a high level immediately animals were transferred from the low- to the high-Ca diet (Fig. 3) and returned to zero only when all the previous $\mathrm{Ca}$ losses had been restored (i,e. after I 5 weeks). Kinetic studies show that the high $\mathrm{Ca}$ retention was due entirely to a high rate of $\mathrm{Ca}$ absorption, faecal endogenous excretion having quickly returned to normal, and that the decrease in retention that occurred as the body stores were replaced resulted from a decrease in the efficiency of $\mathrm{Ca}$ absorption. 
Table 4. Effects of a 4 h EDTA infusion on the serum calcium concentration of wethers given the normal-or the low-Ca diet

(Mean values with their standard errors for four animals/group and results of tests of significance, as determined by the $t$ test)

\begin{tabular}{|c|c|c|c|c|}
\hline & $\begin{array}{c}\text { Normal-Ca } \\
\text { diet }\end{array}$ & $\begin{array}{c}\text { Low-Ca } \\
\text { diet }\end{array}$ & $\begin{array}{c}\text { Pooled SE } \\
\text { of mean } \\
(6 \mathrm{df})\end{array}$ & \\
\hline Total Ca bound by EDTA (mg) & $608 \cdot 5$ & $618 \cdot 5$ & 9.5 & NS \\
\hline Initial serum $\mathrm{Ca}(\mathrm{mg} / \mathrm{l})$ & $110 \cdot 0$ & $109 \cdot 0$ & $2 \cdot 1$ & NS \\
\hline Initial $\mathrm{Ca}$ in blood pool (mg) & 235.7 & $232 \cdot 8$ & 6.4 & NS \\
\hline Serum $\mathrm{Ca}$ after EDTA infusion (mg/l) & $53^{-\circ}$ & $7 \pi \cdot 5$ & $1 \cdot 6$ & $* * *$ \\
\hline \multicolumn{5}{|l|}{ Ca remaining in blood pool after EDTA } \\
\hline infusion (mg) & I I $3 \cdot 0$ & 153.0 & 5.5 & ** \\
\hline Ca mobilized from reserves $(\mathrm{mg})$ & $485 \cdot 8$ & $538 \cdot 7$ & $10 \cdot 9$ & * \\
\hline Ratio, Ca mobilized: total $\mathrm{Ca}$ bound by EDTA & $79 \cdot 8$ & 86.5 & 0.9 & ** \\
\hline One-half recovery time $+(\mathrm{h})$ & $5 \cdot 2$ & $2 \cdot 7$ & 0.4 & $* *$ \\
\hline
\end{tabular}

Since the rate of faecal endogenous excretion of Ca decreased only after a considerable time on the Ca-deficient diet, its mean value ( $16.6 \mathrm{mg} / \mathrm{d}$ per $\mathrm{kg}$ body-weight) found in the kinetic studies (Table 3) can again be used to calculate $\mathrm{Ca}$ absorption rates in the weeks immediately before and after animals were transferred to this diet.

Fig. 4 shows the changes in $\mathrm{Ca}$ absorption that occurred when animals were transferred from the normal- to the high- and from the normal- to the low-Ca diet. Absorption of $\mathrm{Ca}$ was directly related to intake but there was insufficient information to determine if the relationship was linear throughout the range of intakes studied.

Fig. 5 shows that there was a highly significant $(P<0.001)$ linear relationship between the rate of absorption of $\mathrm{Ca}\left(V_{a}\right)$ and the $\mathrm{Ca}$ balance $(\Delta)$ in adult wethers given the various diets (see also Tables 2 and 3 ), and the following regression equation was calculated:

$$
V_{a^{-}}=\mathrm{I} 9 \cdot 7+\mathrm{I} \cdot 0 \mathrm{r} \Delta
$$

This relationship did not hold for animals after they had become adapted to the Cadeficient diet because of their reduced maintenance requirements (due to decreased faecal endogenous excretion).

Urinary excretion of $\mathrm{Ca}$ tended to be higher than normal on the high-Ca diet, but the relationship was not significant.

Neither the quickly exchangeable Ca pool nor the slowly exchangeable bone pool were altered by changes in $\mathrm{Ca}$ intake. The rate of accretion of $\mathrm{Ca}$ into bone also remained constant, but the rate of resorption of $\mathrm{Ca}$ from bone $\left(V_{0}-\right)$ changed considerably. Fig. 6 shows that there was a highly significant $(P<0.001)$ inverse relationship between it and $\mathrm{Ca}$ balance $(\Delta)$, the regression equation being:

$$
V_{0}-=53 \cdot 8-\mathrm{I} \cdot \mathrm{I} \Delta \text {. }
$$


Table 4 summarizes the effects of infusing EDTA into the blood of sheep given the normal- or low-Ca diet. Serum $\mathrm{Ca}$ concentration was depressed less in animals on the low-Ca diet and recovered much more quickly, indicating that they were better able to mobilize their skeletal reserves of $\mathrm{Ca}$ than were animals on the normalCa diet. By assuming that one molecule of EDTA bound one $\mathrm{Ca}^{2+}$ ion and that, as in the cow, $37 \%$ of the body-weight was serum (Muir, Hibbs \& Conrad, I968) it was calculated that $86.5 \%$ of the total Ca complexed by the EDTA was supplied from body reserves in animals on the low-Ca diet. This was significantly more than the $79.8 \%$ supplied from reserves in animals on the normal-Ca diet.

\section{DISCUSSION}

Adaptations in Ca absorption. The results show that, although changes in dietary $\mathrm{Ca}$ intake caused corresponding changes in the rate of $\mathrm{Ca}$ absorption, animals were able to adapt to different intakes by altering the efficiency of absorption of $\mathrm{Ca}$ from the intestine. The rate of adaptation, however, appeared to be influenced by the $\mathrm{Ca}$ status of the body. Wethers previously in $\mathrm{Ca}$ balance adapted rapidly to different intakes, whereas wethers that had suffered substantial losses of Ca when on the Cadeficient diet adapted to the high intake only when all the previous losses had been restored. In addition to taking longer to become adapted, these Ca-deficient animals initially absorbed $\mathrm{Ca}$ from the high-Ca diet at a much greater rate $(55 \mathrm{mg} / \mathrm{d}$ per $\mathrm{kg}$ body-weight) than did animals transferred from the normal-Ca diet $(35 \mathrm{mg} / \mathrm{d}$ per $\mathrm{kg}$ ).

These results support the view of Nicolaysen (1943) that there is an inverse relationship between the efficiency of absorption of $\mathrm{Ca}$ and the degree of mineralization of the skeleton. Further evidence that $\mathrm{Ca}$ absorption is affected by the Ca status of the skeleton has been obtained from work on pregnant and lactating ewes (Braithwaite $e$ t al. 1969, 1970). In those animals the efficiency of absorption of $\mathrm{Ca}$ increased in late pregnancy and early lactation following losses of skeletal reserves of Ca similar to those lost by wethers given the Ca-deficient diet, and returned to normal at the end of lactation after the losses had been made good.

Since the time taken for animals to adapt to a diet appears to depend upon the $\mathrm{Ca}$ concentration of the previous diet, it is not surprising that there are conflicting reports in the literature on the effect of intake on absorption (Scott, 1965 ; Braithwaite \& Riazuddin, 1971). These results emphasize, therefore, that care must be taken in the planning of experiments to ensure that animals have time to become adapted to the experimental diet.

The relationship obtained between the rate of absorption of $\mathrm{Ca}$ and the $\mathrm{Ca}$ balance was very similar to that previously reported by Braithwaite \& Riazuddin (1971) for wethers $\left(V_{a}=2 \mathrm{I} \cdot 8+\mathrm{I} \cdot 08 \Delta\right)$ and confirms that, on average, $20 \mathrm{mg} \mathrm{Ca} / \mathrm{d}$ per $\mathrm{kg}$ body-weight must be absorbed to supply maintenance requirements (i.e. to replace the endogenous losses of $\mathrm{Ca}$ in urine and faeces).

Although the efficiency of absorption of $\mathrm{Ca}$ from the $\mathrm{Ca}$-deficient diet appeared low $(34 \%)$ it was not much lower than values $(37-40 \%)$ found in young growing sheep 
(Braithwaite \& Riazuddin, I97I) and most probably represents the true availability of $\mathrm{Ca}$ in the intestine. This low availability of dietary $\mathrm{Ca}$ in the ruminant is probably due to the presence of Ca-binding substances in the intestine (Smith, McAllan \& Hill, I968; Smith, I969).

Mechanism of Ca absorption. The theory of Wasserman \& Taylor (1969) that Ca absorption involves two processes, a non-saturable diffusional one, related to the $\mathrm{Ca}$ concentration in the intestine, and a saturable active one, independent of concentration, can be used to explain the changes in $\mathrm{Ca}$ absorption observed in the present work. According to this theory, a change in intake would result in an immediate and corresponding change in the diffusional component and therefore total absorption and adaptation to the new intake would then be due to an alteration in the active component.

There is now evidence from work on the rat that active absorption of $\mathrm{Ca}$ is related to $\mathrm{Ca}$ requirements, being high in both young and pregnant animals (Schachter, Dowdle \& Schenker, $\mathrm{I} 960$ ). In the present experiments absorption of $\mathrm{Ca}$ from the high-Ca diet was much greater in Ca-deficient animals than in animals which had been maintained on an adequate $\mathrm{Ca}$ intake. It seems likely therefore that active absorption was responsible for this higher rate of absorption and also for the decrease in absorption which occurred once animals had replaced their earlier losses of $\mathrm{Ca}$.

Mechanism of adaptation. The identity of the factor controlling active absorption of $\mathrm{Ca}$ is at present uncertain. Nicolaysen (1943) suggested that $\mathrm{Ca}$ absorption is related to the degree of saturation of the skeleton with $\mathrm{Ca}$ and this suggestion is supported by the present results. Furthermore, Morrisey \& Wasserman (I97 I have found a corrclation between the amounts of Ca-binding protein in the intestine and bone ash, and Kemm (I972) has found a significant inverse relationship between apparent $\mathrm{Ca}$ absorption and carcass $\mathrm{Ca}$ content.

Despite all the evidence in support of the theory of Nicolaysen, however, no mechanism by which desaturated bone might control $\mathrm{Ca}$ absorption has yet been established.

Adaptations in Ca excretion. When available $\mathrm{Ca}$ in the diet of the wethers was less than their requirements, they slowly reduced the faecal endogenous excretion of $\mathrm{Ca}$. Faecal endogenous $\mathrm{Ca}$ is thought to be that $\mathrm{Ca}$ secreted with the digestive juices which is not subsequently reabsorbed. There is evidence that its amount is related to the $\mathrm{Ca}$ concentration of the serum (Gran, I960; Toverud, 1964), but such a relationship was not obtained (Table 3). Decreases in the serum $\mathrm{Ca}$ concentration would be expected to occur immediately animals were transferred to the low-Ca diet, whereas endogenous excretion of $\mathrm{Ca}$ slowly decreased after several weeks on the $\mathrm{Ca}$-deficient diet.

Ca homoeostasis and the maintenance of body Ca reserves by the adult sheep. When a change in $\mathrm{Ca}$ intake upset the equilibrium between absorption and endogenous excretion, $\mathrm{Ca}$ homoeostasis was achieved by an alteration in the rate of resorption of $\mathrm{Ca}$ from bone. It was also by this mechanism that animals made good their maintenance requirements when receiving the Ca-deficient diet, and replaced their skeletal losses when the dietary $\mathrm{Ca}$ was again plentiful. In adult sheep, as in young growing 
ones (Braithwaite \& Riazuddin, I97I), this appears to be the major process responsible for Ca homoeostasis.

It was $\mathrm{Ca}$ absorption, however, that seemed to be responsible for the long-term control of $\mathrm{Ca}$ metabolism and, in particular, for maintaining the body $\mathrm{Ca}$ reserves. Although endogenous excretion of Ca normally played little part in either homoeostasis or the maintenance of reserves, it did have an important role in times of $\mathrm{Ca}$ deficiency.

I thank Dr R. F. Glascock for his advice and encouragement while this work was being done. I also thank Miss S. Neville and Mr B. Woods for technical assistance and $\mathrm{Mr}$ R. Ellis and Mr A. Wilim for their care of the experimental animals.

\section{REFERENCES}

Agricultural Research Council (1965). The Nutrient Requirements of Farm Livestock. No. 2 Ruminants. London: Agricultural Research Council.

Aubert, J.-P. \& Milhaud, G. (1960). Biochim. biophys. Acta 39, 122.

Braithwaite, G. D., Glascock, R. F. \& Riazuddin, Sh. (1969). Br. F. Nutr. 23, 827 .

Braithwaite, G. D., Glascock, R. F. \& Riazuddin, Sh. (r970). Br. F. Nutr. 24, 66r.

Braithwaite, G. D. \& Riazuddin, Sh. (1971). Br. F. Nutr. 26, 2 I 5.

Goldenberg, H. \& Fcrnandez, A. (1966). Clin. Chem. 12, 871.

Gran, F. C. (1 960). Acta Physiol. scand. 48, Suppl. 167.

Kemm, J. R. (r972). \%. Physiol., Lond. 223, 321.

Lueker, G. E. \& Lofgreen, G. P. (I96I). F. Nutr. 74, 233.

Malm, O. J. (1963). In The Transfer of Calcium and Strontium Across Biological Membranes p. 143.

[R. H. Wasserman, editor]. New York and London: Academic Press Inc.

Manston, R. (1967). F. agric. Sci., Camb. 68, 263.

Morrisey, R. L. \& Wasserman, R. H. (1971). Am. F. Physiol. 220, I509.

Muir, L. A., Hibbs, J. W. \& Conrad, H. R. ( I g68). F. Dairy Sci. 51, 1046.

Nicolaysen, R. (1943). Acta physiol. scand. 5, 200.

Schachter, D., Dowdle, E. B. \& Schenker, H. (r960). Am. F. Physiol. 198, 263.

Scott, D. (1965). Q. fl exp. Physiol. 5o, 312.

Smith, R. H. (1969). Proc. Naty. Soc. 28, I 5 I.

Smith, R. H., McAllan, A. B. \& Hill, W. B. (1968). Proc. Nutr. Soc. 27, 48 A.

Toverud, S. U. (1964). Acta physiol. scand. 62, Suppl. 234.

Visek, W. J., Monroe, R. A., Swanson, E. W. \& Comar, C. L. (1953). J. Nutr. 5o, 23.

Wasserman, R. H. 8 Taylor, A. N. (1969). In Mineral Metabolism Vol. 3, Ch. 5 [C. L. Comar and F. Bronner, editors]. New York and London: Academic Press.

Young, V. R., Richards, W. P. C., Lofgreen, G. P. \& Luick, J. R. (1966). Br. F. Nutr. 20, 783.

Zornitzer, A. E. \& Bronner, F. (1971). Am. F. Physiol. 220, 126r. 